\section{SPOT on, but Landsats off?}

\section{Paris \& Washington}

US and French remote-sensing satellites are facing very different futures. EOSAT, the Earth Observation Satellite Company that operates the two orbiting Landsat satellites for the National Oceanic and Atmospheric Administration (NOAA), has been instructed to begin shutdown procedures for both satellites, putting them in a stand-by mode from the end of this month. By contrast, SPOT, the French Earth-observing satellite, had its third anniversary in space marked by a book about its history*

The chief reason for cutting down the Landsat programme is money. Both Landsats 4 and 5 have exceeded their design lives, and although they are still providing useful information, neither the White House nor Congress has been interested in spending money on upgrading them.

NOAA is obliged to provide EOSAT with money to operate the two satellites, but with with its own budget thinly stretched, the agency has been looking to EOSAT revenues to help defray expenses. EOSAT has responded by arguing that current Landsat revenues are needed to prepare for Landsat 6 , now due to be launched in 1991

EOSAT maintains that $\$ 9.4$ million would allow it to keep operating the two Landsats until the end of the fiscal year (at the end of September). Although the details of a package have not been worked out, NOAA assistant administrator Thomas Pyke last week told a congressional subcommittee that the Bush administration is committed to keeping Landsats 4 and 5 operating until a policy review of the programme is completed. The new National Space Council, chaired by VicePresident Dan Quayle, is coordinating the effort to find money in the budgets of federal agencies that use Landsat data.

Although still operational, SPOT is beginning to show signs of ageing, and a decision will soon have to be made whether to launch its younger sister, SPOT 2, as planned, later this year. To delay the launch would save money in the short term for the financially stretched French space programme, but the gamble could be too risky.

Seen as a white elephant by all other European countries except Sweden and Belgium, SPOT was financed and built almost entirely with French money. Now, with more than 300,000 high-resolution images in its owners' archives for sale to anyone who wants them for as little as $\$ 450$, SPOT has convinced even sceptics of its value.

The US Department of Defense came

* SPOT: Deux Yeux Braques sur la Terre. Bernard Cervelle. Presses du CNRS, Paris: 1989. to respect SPOT two years ago, when Aviation Week and Space Technology published photographs bought over the counter from SPOT Image Corporation that showed Soviet naval installations. The Pentagon was worried by the realization that anyone could also buy pictures of defence installations in the United States.

SPOT 2 should have been launched last year, but a long setback in the European Ariane rocket launch programme meant that SPOT 1 was kept in service. Although it still sends 700 images each day, one of its two data buffers is out of action and a faulty sensor in each of the two highresolution cameras has reduced image quality. If the other buffer should fail,

\section{ENVIRONMENTAL RELEASE}

\section{Munich}

A controversial proposal to plant 40,000 genetically engineered pink petunias has been approved by a West German panel, but the future of the experiment remains in doubt. It is the first time that release of a plant containing recombinant DNA has been approved in West Germany. But the federal Health Ministry must pass judge-

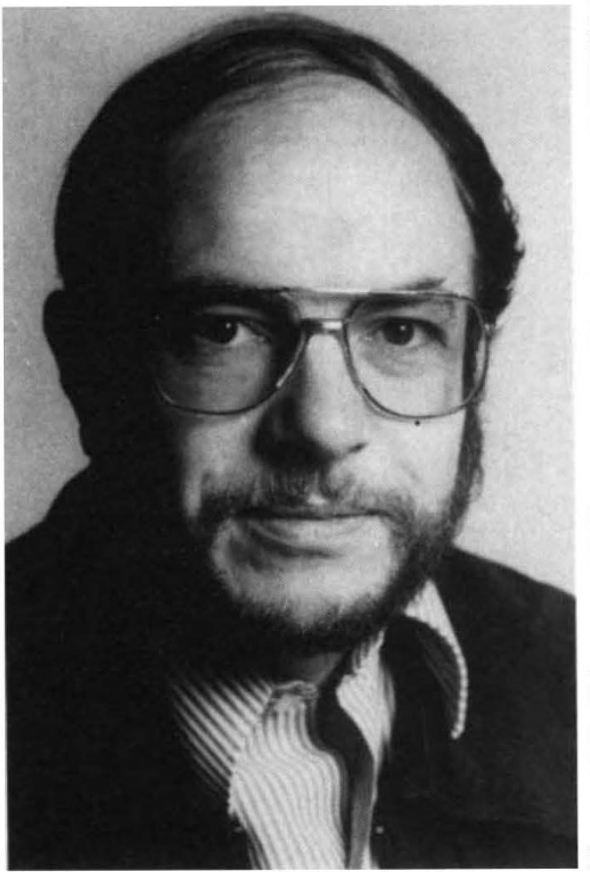

Saedler - expressing a lack of optimism. ment on the experiment before planting can begin.

The experiment itself is not expected to pose a danger to the environment, but opponents fear that it will convince the public that all release experiments are harmless. The experiment is important because it should force better definition for each phase of the now vague licensing procedure. Challenges to approval could come from one of several offices within the details of some of the most strategic parts of the globe would be unavailable, and the satellite's commercial value would be drastically reduced

The French space research centre (CNES) has booked a place for SPOT 2 aboard Ariane flight 34, due in September. But the French space programme is heaving under the burden of recent financial commitments to the European Space Agency and CNES would like to delay the launch so long as SPOT 1 is working well. Although CNES says that SPOT 2 could always be launched at short notice, if the flight 34 option is not taken up, a failure in SPOT 1 would leave France with only an exotic photograph album to sell until another launcher is free, which might not be for several months.

Peter Coles \& Joseph Palca

\title{
Pink petunias sow controversy in West Germany
}

federal Health Ministry, the federal Environment Ministry or the Land of North Rhine-Westphalia.

Biological release is a controversial issue in West Germany, as shown by the storm of protest that greeted Bayreuth geneticist Walter Klingmüller when, in 1987, he carried out an unauthorized experiment with nitrogen-fixing Rhizobium bacteria (see Nature 328, 568; 1987). In 1985, there was a bomb attack on the Max Planck Institute (MPI) for Breeding Research in Cologne, which has planned the petunia experiment.

Release experiments must now be undertaken in the legal vacuum preceding the long-awaited introduction into parliament of a 'basic law' for regulating genetic engineering. The Central Commission for Biological Safety, the body that unanimously approved the petunia experiment, can request only voluntary compliance with its regulations.

The experiment will demonstrate the behaviour in petunia of so-called jumping genes' (transposons). A maize gene has been introduced into the petunia that turns them an unnatural pink colour. If a transposon should jump into the middle of this coloration gene, it is expected to leave parts of the flower white. Among other things, the researchers hope to tell whether transposons move systematically to particular sites, which may have an important bearing on plant evolution.

The jumping event is expected to occur in only one out of every 5,000 to 10,000 plants. For this reason, the experiment must be performed on such a large scale outside a greenhouse.

Heinz Saedler of MPI, the project leader, says that planting must begin by July at the latest if the experiment is to be done this year. But he is "not too optimistic", given the number of federal and Land authorities that might hold it up. 